\title{
Effects of the Global Financial Crisis on the Agency Cost of Islamic Banks and Conventional Banks
}

\author{
Talla M Aldeehani \\ Correspondence: Talla M Aldeehani, College of Business Administration, Kuwait University, Kuwait. \\ Received: October 30, 2017 \\ Accepted: November 14, 2017 \\ Available online: November 16, 2017 \\ doi:10.11114/afa.v4i1.2799 \\ URL: https://doi.org/10.11114/afa.v4i1.2799
}

\begin{abstract}
In this paper, we investigate the effect of the 2008 global financial crisis on the agency cost (AC) of Islamic banks (IBs) and conventional banks (CBs). Many pioneering scholars (see, for example, Archer et al., 1998) have recognized fundamental differences in the capital structures and risks of IBs compared to CBs and called for more empirical testing of these issues. This effort is in response to those calls. Focusing on AC, we collected data for all Gulf Cooperation Council (GCC) banks satisfying the period from 2001-2014. The data was split into "before" and "after" the 2008 crisis. Although statistically insignificant, the analysis shows higher AC for IB compared to CBs before and after the crisis. However, we provide evidence of significant differences in AC causal models for the two types of banks. For conventional banks, only profitability factors explain variability in AC before and after the crisis. For Islamic banks, however, in addition to profitability, liquidity, deposits and financing facilities matter depending on the status of the economy. We provide further discussions, implications, and recommendations.
\end{abstract}

Keywords: Islamic banking, GCC banks, agency cost, 2008 crisis

\section{Introduction}

Agency problem exists when there is a conflict of interest between management of the company and the owners. Agency cost (AC) is, simply, the extra cost incurred by the firm (owners) as a direct result of management misconduct. This extra cost is called agency cost because the manager, acting as the agent on behalf of the owner of the company, has taken decisions with financial implications, on the firm, in conflict with the owner's interest. Unlike conventional banks (CBs), Islamic banks (IBs) do not treat investors' deposits as liabilities. They act as agents, on behalf of the investors, to invest the many deposited in the banks the way they see fit. Depositors are neither lender (as in conventional banking) nor shareholding owners. They don't have the right to vote, and they don't have priority of claim in case of bankruptcy. As such, they bear all the risk, and the IB assumes zero risks (see Aldeehani et al., 1999). With this background, managers of the IB are acting as "double agents". They are agents working on behalf of the owners of the bank and agents working on behalf of the depositors. Assuming zero-risk deposits, IBs are tempted to take risky investments' decisions. Deposits in CB are considered liability and depositors have priority claims in case of bankruptcy. CBs are assumed to be more cautious on how to utilize and invest deposited funds.

Recognizing these fundamental differences between IBs and CBs, one would assume different theoretical and practical implications on their ACs. The relevant literature is reviewed in the context of these implications. One important explanation is that if the IB is tempted to take risks with depositors' money at times of stability (before the financial crisis), how would it respond, regarding the extra AC (if any), at times of financial stress (during the crisis)? Furthermore, and other than the corporate structure, what are the determinants of its AC compared to the CB?

The existing literature does not provide answers to these specific and fundamental questions. It is the role of this research to provide such answers. Numerous literature is available on causal modeling of bank AC. As such, we review only the relevant literature, with the objective of understanding how the relationship between AC and other performance indicators is modeled and what predictor variables were used. The focused review should help us select the proper variables and develop our research hypotheses and model.

In the next section, we review the relevant literature where we identify our variable of concern and potential explanatory variables then develop our research hypotheses. This is followed by a discussion of our methodology and data. We next test the research hypotheses and estimate the causal models for each bank type. We then discuss and summarize the results. We end the paper with a conclusion highlighting the purpose of the research and possible 
implications and recommendations based on the main results.

\section{Literature Review}

Several studies, for non-financial companies, have defined agency cost differently. Using the expense ratio and the asset turnover on a sample of small firms, Ang et al. (2000) was the first to propose proxies of AC. Many others followed, including Singh \& Davidson (2003), Florackis (2008), Wellalage \& Locke (2012). Rashid (2104), used the proposed measures and suggested a third proxy: the Q-free cash flow interaction. For the banking industry, researchers often use the equity capital ratio as a proxy of AC (see, for example, Berger \& Patti, 2006 and Ismail \& Pratomo, 2007). Others used the majority shareholding representation as a measure of AC (see, for example, Naushad \& Malik, 2015).

In our review of the relevant literature, we differentiate between two AC causal modeling. The first considers AC as an explanatory variable in a bilateral relationship or among univariates. One example of such modeling is the work of Berger \& Patti (2006) who investigate, among other variables, the effect of AC on firm performance. They used the ratio of equity capital to total assets as a proxy. They, particularly, used 'reverse causality' to test effects on AC. Their results were consistent with the propositions of the agency theory. Mohammed (2013) investigated the effect of AC, measured as the asset turnover, on financing structures of Nigerian firms. His results were also consistent with the agency theory propositions. Easterbrook (2017) proposed, in an abstract paper, an agency-cost explanation of dividend policy. Naushad \& Malik (2015) considered AC, as a corporate governance variable, to explain variability in firm performance. Their results indicate a negative effect on firm performance measured by Tobin's q, which also appeared consistent with the agency theory argument that efficient management (low AC) results in better performance.

The second type of causal modeling considers $\mathrm{AC}$ as a dependent variable determined by some explanatory variables. One example of such modeling is the pioneering work of Ang et al. (2000). They investigated the effects of various ownership structures predictors on agency cost. Their results indicate that better owner/lender monitoring leads to lower ACs which is consistent with the assumptions of agency theory. Similarly, Doukas et al. (2000) found that better monitoring activities of security analysts reduces ACs. Other examples using variables of ownership structure as explanatory variables, include the work of Gul et al (2012) who used the assets turnover ratio as a proxy of AC. Their results support the findings of, earlier and similar studies. Using data from 775 listed companies in Shanghai and Shenzhen stock markets in China for the period 2010-2012, Zheng (2013) examined the effect of the firm capital structure on AC measured as the administrative expense rate and assets turnover ratio and reported evidence of a negative effects. Morris \& Roseman (2015) used management opaqueness as a proxy of AC and found that more dividend payments to owners remove cash from the hands of managers and reduces AC.

Earlier theoretical propositions relevant to ACs of the banking industry were provided by Easterbrook (1984) highlighting dividend policy effects on AC and Archer et al. (1998) highlighting the effect of the unique capital structure of IBs. Building on Archer et al.'s theoretical propositions, Safieddine (2009) provides another theoretical approach to investigating agency theory relevant to IBs. He argues that ACs in banks are likely to be evident due to the opaqueness nature regarding information disclosure. This particular issue was investigated for the US banking industry earlier by Berger \& Patti (2006) who provided evidence of the effect of bank capital structure on the level of its AC. Ismail \& Partomo (2007) conducted a similar investigation, for the Malaysian banking industry, and end up with similar conclusions.

Comparing CBs to IBs, Aljifri \& Khandelwal (2013) conclude, in an abstract paper, that Islamic financial institutions have fewer agency problems than their conventional counterparts, but failed to provide scientific evidence to support their arguments.

Rahman and Danbatta (2016) examined IBs in Bahrain and Malaysia to study the determinants of ethical identity disclosures in the period between 2007 and 2011. They concluded that their results conflicted with the agency theory. Imran et al. (2013) examined the relationship between banks' dividend policy and AC in the Islamic banking industry of Pakistan and found support for the propositions of agency theory.

In a more recent empirical attempt, but rather with old data (2005-2009), Fayed \& Ezzat (2017) provided evidence of principal-agent conflicts in both conventional and IB on a sample of 105 banks 8 Arab countries. AC of Islamic banking was also investigated by Shoaib (2011) and found some effects of capital structure. Similar results were found by Yeh (2011) for the conventional banking industry in Taiwan.

Meero (2015) examined the relationship between capital structure and performance in GCC banks. Contradicting with the theoretical and applied research on Islamic banking, he reported, abstractly, that capital structures of IBs and CBs are similar. However, he reported an association between capital structure and AC (represented by E/A ratio). Arouri et al. (2011) provided evidence of the effect of ownership structure and corporate governance on bank performance for the GCC banking industry. Their sample covered 27 banks. They called for better internal control. In his study on the determinants of IB and CB performance in the GCC countries, Zeitun (2012) repeated the call for the need to increase 
internal control mechanisms implying increased agency problems. Another call for improving internal control, based on GCC Islamic banking sample was also made by Harun (2016). In a more recent study on GCC Islamic banking, AlQanea \& Hamdan (2017) provided evidence of an "inverse effect of board independence on IBs performance" implying the effect of board structure on AC.

Discussions of this literature review on AC can be summarized by the following remarks:

1. AC is the extra cost incurred by the firm as a result of management misconduct.

2. The main proposition of agency theory is that a well-managed and better-performed firm is the one with less conflict of interest between managers and owners resulting in less ACs.

3. The literature reveals three widely used proxies of AC. These are the operating expense ratio, the asset turnover ratio and the equity capital ratio (E/A). Some researchers used the overhead expense ratio and the interaction between value and cash flow.

4. AC and its relationship to firm performance has taken two forms of causal modeling in the literature. In the first form, it is being considered as an explanatory variable affecting performance. In the second form, AC is the explained (dependent) variable.

5. Most of the research considering the first form of modeling confirms the inverse relationship of AC with firm performance and approves the propositions of agency theory.

6. Most of the research considering the second form of modeling also confirms an inverse relationship of AC and performance and reveals that $\mathrm{AC}$ is a significant explanatory variable of firm performance.

7. For the banking industry, $\mathrm{AC}$ is even more evident due to its opaqueness nature.

8. Because of the unique capital structure of IBs, scholars have been calling for improving internal control mechanism to mitigate for the increased AC.

9. The literature does not help much in the understanding of how the AC of IBs and CBs is explained (by selected corporate performance indicators) before and after the 2008 global financial crisis.

It is the later remark that motivated the undertaking of this research. In this paper, we opt for the first causal modeling, considering agency cost as the dependent variable. We want to understand what predictor variables explain the variability of the $\mathrm{AC}$ of an IB compared to a $\mathrm{CB}$. We also need to understand how the causal model is affected by the 2008 global financial crisis.

\section{Variables and Hypotheses Development}

Following the previous studies, in this paper, we use the ratio of equity to total assets as a proxy of AC. The hypothetical argument is that management misconduct leads to an increase of debt ratio or a decrease of equity capital, which we consider as the variable of concern. We also selected seven variables representing four groups of bank performance. The first group is "profitability" which is represented by the return on assets ratio (ROA) and the return on equity ratio (ROE). The second group is "capital-structure" represented by deposits to assets (DoA), loans to assets (LoA) and loans to deposits (LoD). The third groups is "short-term liquidity" represented by current assets to current liabilities (CAoCL). The fourth group is "risk" represented by the overall risk index (RI) of the bank.

Following Aldeehani (2016), RI is calculated as

$$
R I=\left(\frac{R O A+E / A}{\sigma_{R O A}}\right)
$$

Where $R I$ is the risk index, $R O A$ is the rate of return on assets, $E / A$ is equity over total assets and $\sigma_{R O A}$ is the standard deviation of $R O A$. The lower the $R I$ the higher the overall risk of the bank.

Based on the conclusion of the reviewed literature, the selected variable of concern and the explanatory variables, we propose the following research hypotheses:

Hypothesis 1: Irrespective of the 2008 global financial crisis, ACs variable and all of the selected performance variables of IBs and CBs are different.

Hypothesis 2: ACs variable and all of the selected performance variables of IBs before the crisis and after the crisis are different.

Hypothesis 3: ACs variable and all of the selected performance variables of $\mathrm{CBs}$ before the crisis and after the crisis are different.

Hypothesis 4: Before the crisis, ACs variable and all of the selected performance variables of IBs and CBs are different.

Hypothesis 5: After the crisis, ACs variable and all of the selected performance variables of IBs and CBs are different.

Hypotheses 6-12: Before the crisis, each of the selected performance indicators has a significant effect on AC of IBs.

Hypotheses 13-19: After the crisis, each of the selected performance indicators has a significant effect on AC of IBs. 
Hypotheses 20-26: Before the crisis, each of the selected performance indicators has a significant effect on AC of CBs.

Hypotheses 27-33: After the crisis, each of the selected performance indicators has a significant effect on AC of CBs.

\section{Data and Methodology}

To compare between Islamic and conventional banking, the GCC region has always been a credible choice of researchers for obvious reasons. First of all, this is a region where Islamic banking was originated. It contains the oldest and largest IBs. It is the region that developed most of the regulations of Islamic banking. Furthermore, GCC countries share many similarities in social culture, language, economic environment ... etc.

We wanted to cover the broadest period for most of the banks. Due to the availability of financial reports we opted for the period from the year 2001 till the year 2014. During this period, many banks were canceled out due to the absence of data for the period, and we ended up with 19 banks. 12 of which are conventional and 7 are Islamic.

To test our research hypotheses 1 to 5 , we would compare the means of more than two independent samples using the one way ANOVA procedure if data is normal. Otherwise we apply the nonparametric Kruskal-Wallis $H$ test which does not assume a normal distribution of the residuals. Grouping of the variables, in the two tests, is based on the status of the economy (before and after the 2008 crisis). Causality relationship is investigated using GLS panel-data regression modeling.

\section{Tests and Estimations}

The results of the normality test based on Kolmogorov-Smirnov and Shapiro-Wilk are presented in Table 1 below.

Table 1 . Results of normality test

\begin{tabular}{|c|c|c|c|c|c|c|}
\hline & \multicolumn{3}{|c|}{ Kolmogorov-Smirnov } & \multicolumn{3}{|c|}{ Shapiro-Wilk } \\
\hline & Statistic & $\mathrm{df}$ & Sig. & Statistic & df & Sig. \\
\hline$A C$ & .122 & 266 & $.000 * * *$ & .886 & 266 & $.000 * * *$ \\
\hline LoA & .071 & 266 & $.002 * * *$ & .982 & 266 & $.002 * * *$ \\
\hline$D o A$ & .229 & 266 & $.000 * * *$ & .651 & 266 & $.000 * * *$ \\
\hline LoD & .480 & 266 & $.000 * * *$ & .203 & 266 & $.000 * * *$ \\
\hline CAoCL & .214 & 266 & $.000 * * *$ & .571 & 266 & $.000 * * *$ \\
\hline $\boldsymbol{R O A}$ & .419 & 266 & $.000 * * *$ & .086 & 266 & $.000 * * *$ \\
\hline $\boldsymbol{R O E}$ & .434 & 266 & $.000 * * *$ & .074 & 266 & $.000 * * *$ \\
\hline $\boldsymbol{R I}$ & .127 & 266 & $.000 * * *$ & .832 & 266 & $.000 * * *$ \\
\hline
\end{tabular}

*** Significant at the $1 \%$ level

The results of the normality test for the two methods appear to be statistically significant for all the variables rejecting the null hypothesis of normality. Therefore, the Kruskal-Wallis nonparametric test to compare means ranks is the proper selection. The means rank of all the variables including AC is presented in Table 2.

Table 2. Means rank of the Kruskal-Wallis test.

\begin{tabular}{|c|c|c|c|c|}
\hline Category & Variable & Bank type & $\mathrm{N}$ & Mean rank \\
\hline Variable & $A C$ & Conventional & 168 & 134.49 \\
\hline of concern & & Islamic & 98 & 131.80 \\
\hline \multirow{6}{*}{ 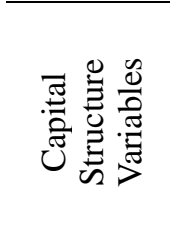 } & \multirow[t]{2}{*}{$L o A$} & Conventional & 168 & 96.23 \\
\hline & & Islamic & 98 & 197.39 \\
\hline & \multirow[t]{2}{*}{ DoA } & Conventional & 168 & 154.99 \\
\hline & & Islamic & 98 & 96.66 \\
\hline & \multirow[t]{2}{*}{ LoD } & Conventional & 168 & 95.16 \\
\hline & & Islamic & 98 & 199.22 \\
\hline \multirow{2}{*}{$\begin{array}{l}\text { Liquidity } \\
\text { Variable }\end{array}$} & \multirow[t]{2}{*}{ CAOCL } & Conventional & 168 & 157.27 \\
\hline & & Islamic & 98 & 92.74 \\
\hline \multirow{4}{*}{ 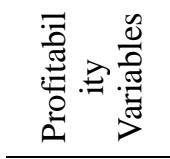 } & \multirow[t]{2}{*}{$R O A$} & Conventional & 168 & 142.54 \\
\hline & & Islamic & 98 & 118.01 \\
\hline & \multirow[t]{2}{*}{$R O E$} & Conventional & 168 & 142.13 \\
\hline & & Islamic & 98 & 118.70 \\
\hline Risk & \multirow[t]{2}{*}{$\boldsymbol{R I}$} & Conventional & 168 & 166.27 \\
\hline Variable & & Islamic & 98 & 77.33 \\
\hline
\end{tabular}

Except for AC, differences of the mean ranks of all the variables are evident. The statistical significance of these differences is tested by Kruskal Willis test and presented in in table 3 below.

The results of Kruskal Wallis $H$ test are presented in Table 3. 
Table 3. Results of Kruskal Wallis $H$ test based on bank type

\begin{tabular}{rrrrrrrrr}
\hline & $\boldsymbol{A C}$ & $\boldsymbol{L o A}$ & $\boldsymbol{D o A}$ & $\boldsymbol{L o D}$ & $\boldsymbol{C A o C L}$ & $\boldsymbol{R O A}$ & $\boldsymbol{R O E}$ & $\boldsymbol{R I}$ \\
\hline$\chi^{2}$ & .076 & 107.009 & 35.575 & 113.251 & 43.546 & 6.290 & 5.739 & 82.727 \\
$\boldsymbol{D} \boldsymbol{f}$ & 1 & 1 & 1 & 1 & 1 & 1 & 1 & 1 \\
Sig. & .783 & $.000 * * *$ & $.000 * * *$ & $.000 * * *$ & $.000 * * *$ & $.012 * *$ & $.017 * *$ & $.000 * * *$ \\
\hline
\end{tabular}

$* * *$ Significant at the $1 \%$ level, $* *$ Significant at the $5 \%$ level

Chart 1 below depicts this conclusion.

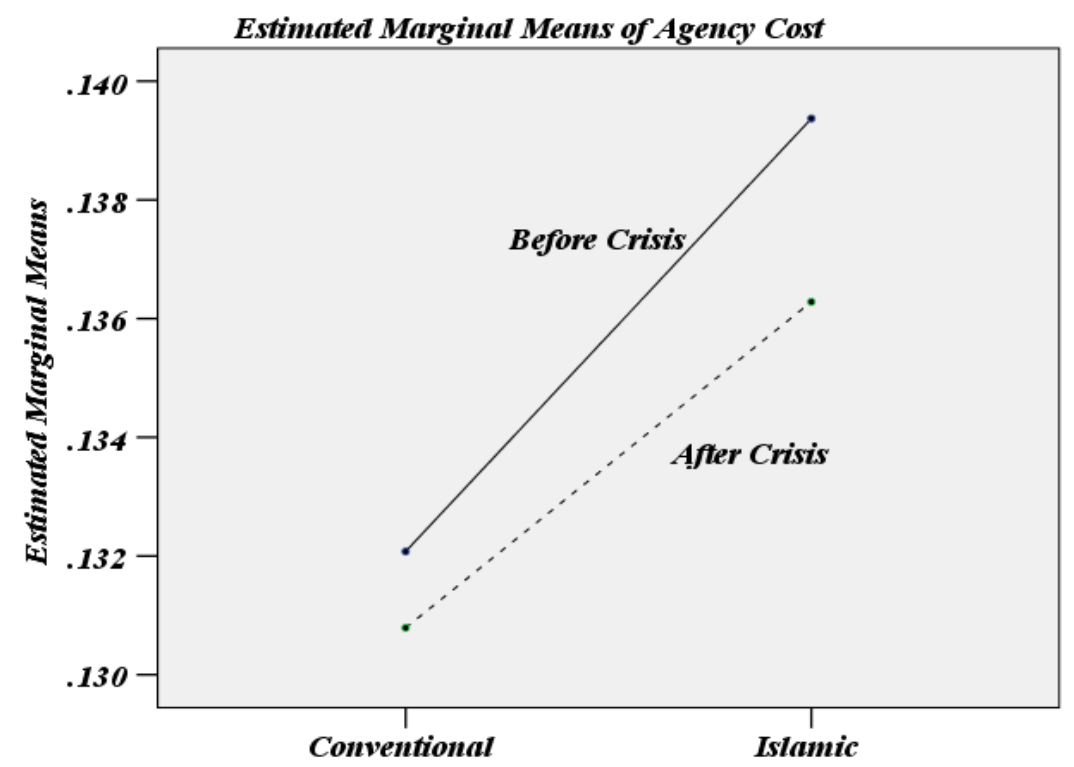

Chart1. Estimated marginal means of AC

As expected, except for the dependent variable (AC), the mean ranks of all the explanatory variables for IBs and CBs are significantly different. Only the two variables representing profitability are significant at the $5 \%$ level. The rest of the variables are statistically significant at the $1 \%$ level. These results confirm our first hypothesis for all explanatory variables but not for the $\mathrm{AC}$ variable. However, the results confirm a significant difference in agency cost when comparing $\mathrm{CB}$ to IB.

Although the result is statistically insignificant, Chart 1 shows clearly how Islamic banks are bearing higher agency cost than conventional banks before the crisis and even higher after the crisis. This confirms the notion we discussed earlier that IBs are lagging in agency cost management when compared to conventional banks. This result disputes the abstract argument made by Aljifri \& Khandelwal (2013) that IBs have fewer agency problems compared to CBs.

The specific significance of the mean rank differences for each bank type irrespective of the 2008 global financial crisis is tested next and presented in table 4.

Table 4. Results of Kruskal Wallis $H$ test of mean ranks differences before and after the crisis

\begin{tabular}{rrrrrrrrrr}
\hline \multicolumn{1}{l}{ Islamic } & & $\boldsymbol{A C}$ & $\boldsymbol{L o A}$ & $\boldsymbol{D o A}$ & $\boldsymbol{L o D}$ & $\boldsymbol{C A o C L}$ & $\boldsymbol{R O A}$ & $\boldsymbol{R O E}$ & $\boldsymbol{R I}$ \\
& $\chi^{2}$ & .129 & 3.944 & 2.477 & .035 & 6.202 & 6.167 & 9.663 & .119 \\
& $\boldsymbol{D} \boldsymbol{f}$ & 1 & 1 & 1 & 1 & 1 & 1 & 1 & 1 \\
Conv. & Sig. & .720 & $.047 * *$ & .116 & .851 & $.013 * *$ & $.013 * *$ & $.002 * * *$ & .730 \\
& $\chi^{2}$ & .122 & 2.083 & 4.423 & 3.374 & 3.831 & 26.770 & 27.033 & .150 \\
& $\boldsymbol{d} \boldsymbol{f}$ & 1 & 1 & 1 & 1 & 1 & 1 & 1 & 1 \\
& Sig. & .727 & .149 & $.035^{* *}$ & $.066^{*}$ & $.050^{* *}$ & $.000^{* * *}$ & $.000^{* * *}$ & .699 \\
\hline
\end{tabular}

*** Significant at the $1 \%$ level, ** Significant at the $5 \%$ level, * Significant at the $10 \%$ level

The results indicate that the mean ranks of LoA, CAoCL, ROA, and ROE for IBs before and after the crisis are significantly different. For CBs, the mean ranks of DoA, LoD, CAoCL, ROA, and ROE before and after the crisis are significantly different. The results suggest that the performance indicators of profitability and liquidity are the ones that change after the crisis. For CBs, the performance indicators that changed after the crisis were profitability, liquidity and capital structure. These results may imply different causal modeling for the different type of banks before and after the crisis.

The significance of the mean rank difference for IBs versus CBs is tested next and presented in Table 5. 
Table 5. Results of Kruskal Wallis $H$ test for $\boldsymbol{I B} s$ vs $\boldsymbol{C B}$ s before and after crisis

\begin{tabular}{|c|c|c|c|c|c|c|c|c|c|}
\hline & & $A C$ & LoA & DoA & LoD & CAoCL & $\boldsymbol{R O A}$ & $R O E$ & $R I$ \\
\hline$\approx \infty \cong$. & $\chi^{2}$ & .192 & 60.897 & 19.389 & 65.343 & 25.992 & 1.842 & .122 & 40.006 \\
\hline 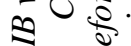 & $\tilde{D} f$ & 1 & 1 & 1 & 1 & 1 & 1 & 1 & 1 \\
\hline & Sig. & .661 & $.000 * * *$ & $.000 * * *$ & $.000 * * *$ & $.000 * * *$ & .175 & .726 & $.000 * * *$ \\
\hline$\approx \infty \equiv$ & $\chi^{2}$ & .014 & 44.740 & 18.096 & 48.368 & 17.156 & 5.439 & 8.801 & 43.378 \\
\hline$\triangleq \quad \frac{\pi}{\sigma}$ & $D f$ & 1 & 1 & 1 & 1 & 1 & 1 & 1 & 1 \\
\hline & Sig. & .907 & $.000 * * *$ & $.000 * * *$ & $.000 * * *$ & $.000 * * *$ & $.020 * *$ & $.003 * * *$ & $.000 * * *$ \\
\hline
\end{tabular}

$* * *$ Significant at the $1 \%$ level, ** Significant at the $5 \%$ level

The results in Table 5 show that only the mean ranks of the profitability indicators for IBs versus CBs before the 2008 crisis were not significantly different. However, they were all significantly different "after" the crisis. This may also indicate different causal modeling.

Our data are of panel nature, and strongly balanced, covering 7 years before the crisis and 7 years during and after the crisis. The organization of such data calls for a causal modeling using panel data regression. Therefore, we adopt a generalized least square (GLS) model with panel data. However, we need to take care of some of the major problems of linear regression models. These problems include stationarity of data, co-linearity of the explanatory variables, heteroskedasticity, and autocorrelation.

Autocorrelations and heteroskedasticity problems can be avoided since we are confined to a time span of only 14 years in addition to the use of robust standard error in the estimation process. To test for stationarity in the series property of the dependent variable, we use the Levin-Lin-Chu unit root. The null hypothesis of this test is that panels contain unit roots against the alternate hypothesis that panels are stationary. The results of this test are presented in Table 6 below.

Table 6. Results of the unit root test

\begin{tabular}{|c|c|c|c|}
\hline Variable & Statistic & p-value & Status \\
\hline$A C$ & -2.5281 & $0.0057 * * *$ & \multirow{8}{*}{ 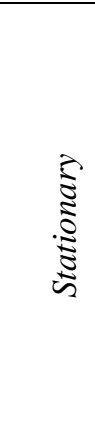 } \\
\hline $\operatorname{LoA}$ & -10.2914 & $0.0000 * * *$ & \\
\hline$D o A$ & - 4.3917 & $0.0000 * * *$ & \\
\hline$L o D$ & - 4.4002 & $0.0000 * * *$ & \\
\hline CAoCL & - 2.3211 & $0.0101 * *$ & \\
\hline $\boldsymbol{R O A}$ & - 4.1803 & $0.0000 * * *$ & \\
\hline$R O E$ & $-\quad 2.7477$ & $0.0030 * * *$ & \\
\hline$R I$ & $-\quad 3.5655$ & $0.0002 * * *$ & \\
\hline
\end{tabular}

*** Significant at the $1 \%$ level, ** Significant at the $5 \%$ level

As shown, unit roots are rejected for all the variables indicating data stationary.

To test for co-linearity among predictor variables, we apply the variance inflation factor (VIF). VIF measures the variance increased in a regression coefficient as a direct result of co-linearity with another variable. To perform the VIF procedure, we first estimate an ordinary least squares regression using one of the subsets of our data. As an example, we use the data for IBs before the crisis with $\mathrm{AC}$ as a dependent variable. The results of this procedure are illustrated in Table 7 .

Table 7. Results of testing co-linearity using the variance inflation factor

\begin{tabular}{|c|c|c|c|c|c|c|}
\hline \multirow[b]{2}{*}{ Model } & \multirow[b]{2}{*}{$\boldsymbol{B}$} & \multirow[b]{2}{*}{ Std. Error } & \multirow[b]{2}{*}{$T$} & \multirow[b]{2}{*}{ Sig. } & \multicolumn{2}{|c|}{$\begin{array}{c}\text { Co-linearity } \\
\text { Statistics }\end{array}$} \\
\hline & & & & & Tolerance & VIF \\
\hline (Constant) & .283 & .069 & 4.130 & .000 & & \\
\hline $\operatorname{LoA}$ & -.160 & .095 & -1.679 & .101 & .579 & 1.729 \\
\hline$D o A$ & -.057 & .021 & -2.770 & .008 & .655 & 1.527 \\
\hline$L o D$ & -.001 & .000 & -1.704 & .096 & .601 & 1.664 \\
\hline CAoCL & .010 & .005 & 2.097 & .042 & .835 & 1.197 \\
\hline $\boldsymbol{R O A}$ & 3.074 & .501 & 6.134 & .000 & .408 & 2.451 \\
\hline$R O E$ & -.376 & .058 & -6.451 & .000 & .403 & 2.484 \\
\hline$R I$ & .000 & .001 & .289 & .774 & .555 & 1.801 \\
\hline
\end{tabular}

The results relevant to the variance inflation factor are shown in the last two columns of Table 7. The scores of the VIF test are less than 10 (a rule of thumb) for all predictor variables indicating a non-co-linearity problem. 
As we took care of all potential problems, we now develop our main causal model to examine the effect of the selected performance indicators on banks' ACs. Our GLS panel regression model is of the form:

$$
A C_{i t}=\alpha+\beta_{1} L o A_{i t}+\beta_{2} D o A_{i t}+\beta_{3} L o D_{i t}+\beta_{4} C A o C L_{i t}+\beta_{5} R O A_{i t}+\beta_{6} R O E_{i t}+\beta_{7} R I_{i t}+u_{i t}+\varepsilon_{i t}
$$

Where $A C_{i t}$ is the dependent variable representing the AC variable. $i$ is the entity and $t$ is time. $L o A, D o A, L o D$, $C A o C L, R O A, R O E$ and $R I$ are the explanatory variables explained earlier. $\alpha, \beta_{1}, \beta_{2}, \beta_{3} \beta_{4} \beta_{5} \beta_{6}$ and $\beta_{7}$ are coefficients. $u_{i t}$ is the between-entity error and $\varepsilon_{i t}$ is the within-entity error.

By estimating the model for IBs before the crisis, we get the results shown in Table 8 .

Table 8. Results of the GLM panel data regression: IBs before crisis

\begin{tabular}{|c|c|c|c|c|c|c|}
\hline & Coef. & Robust Std. Err. & $\mathrm{z}$ & $\mathrm{P}>|\mathrm{z}|$ & \multicolumn{2}{|c|}{ [95\% Conf. Interval] } \\
\hline$L o A, \boldsymbol{\beta}_{1}$ & -.1599104 & .1142295 & -1.40 & 0.162 & -.3837962 & .0639754 \\
\hline$D o A, \boldsymbol{\beta}_{2}$ & -.0571336 & .016384 & -3.49 & $0.000 * * *$ & -.0892456 & -.0250215 \\
\hline$L o D, \boldsymbol{\beta}_{3}$ & -.0007578 & .0002275 & -3.33 & $0.001 * * *$ & -.0012036 & -.000312 \\
\hline$C A o C L, \boldsymbol{\beta}_{4}$ & .0103957 & .008555 & 1.22 & 0.224 & -.0063718 & 0271632 \\
\hline$R O A, \boldsymbol{\beta}_{5}$ & 3.074295 & .5775673 & 5.32 & $0.000 * * *$ & 1.942284 & 4.206306 \\
\hline$R O E, \boldsymbol{\beta}_{6}$ & -.3759942 & .1161572 & -3.24 & $0.001 * * *$ & -.6036581 & -.1483303 \\
\hline$R I, \boldsymbol{\beta}_{7}$ & .0001808 & .0010156 & 0.18 & 0.859 & -.0018097 & .0021713 \\
\hline _cons, $\boldsymbol{\alpha}$ & .2829412 & .0758171 & 3.73 & $0.000^{* * *}$ & .1343424 & .4315401 \\
\hline
\end{tabular}

$A C$ is the dependent variable, $R^{2}=0.6886, N=49$

*** Significant at the $1 \%$ level

The results of Table 8 indicate that IBs' AC before the 2008 crisis is determined by the size of deposits to total assets, the size of loans (Islamic lending facilities) to deposits and the profitability indicators. The sign of the effect is negative except for ROA. The negative sign is logical and in line with the agency theory proposition. That is better performance is associated with better management of the firm resources implying lower ACs. The positive sign effect associated with ROA can be interpreted by the fact that the dependent variable (AC measured as $\mathrm{E} / \mathrm{A}$ ) and the independent variable (ROA) are sharing the same denominator. The same denominator for the dependent and independent variables implies a positive sign.

Table 9 shows the results of estimating the model for IBs after the crisis.

Table 9. Results of the GLM panel data regression: Islamic after crisis

\begin{tabular}{rclllll}
\hline & Coef. & Robust Std. Err. & $\mathrm{z}$ & $\mathrm{P}>|\mathrm{z}|$ & \multicolumn{2}{l}{ [95\% Conf. Interval] } \\
\hline LoA, $\boldsymbol{\beta}_{\boldsymbol{1}}$ & .0165927 & .0769346 & 0.22 & 0.829 & -.1341964 & .1673817 \\
DoA, $\boldsymbol{\beta}_{\mathbf{2}}$ & -.056436 & .0360601 & -1.57 & 0.118 & -.1271126 & .0142406 \\
LoD, $\boldsymbol{\beta}_{3}$ & .0003346 & .0004756 & 0.70 & 0.482 & -.0005975 & .0012668 \\
CAoCL, $\boldsymbol{\beta}_{\boldsymbol{4}}$ & .003926 & .0015742 & 2.49 & $0.013^{* *}$ & .0008406 & .0070114 \\
$R O A, \boldsymbol{\beta}_{\boldsymbol{5}}$ & 4.743763 & .8978036 & 5.28 & $0.000^{* * *}$ & 2.9841 & 6.503426 \\
$R O E, \boldsymbol{\beta}_{\boldsymbol{6}}$ & -.4997435 & .0936624 & -5.34 & $0.000^{* * *}$ & -.6833184 & -.3161687 \\
$R I, \boldsymbol{\beta}_{7}$ & -.0003557 & .0003944 & -0.90 & 0.367 & -.0011287 & .0004172 \\
cons, $\boldsymbol{\alpha}$ & .1337127 & .0426851 & 3.13 & $0.002^{* * *}$ & .0500515 & .2173739 \\
\hline
\end{tabular}

$\mathrm{AC}$ is the dependent variable, $\mathrm{R}^{2}=0.6718, \mathrm{~N}=49$

*** Significant at the $1 \%$ level, Significant at the $5 \%$ level

Based on these results, AC of IBs after the crisis is explained differently. Liquidity explains it with a positive sign, ROA with a positive sign and ROE with a negative sign. The positive sign of liquidity would only mean that the more short-term liquidity is available to IBs' managers after the crisis the higher the AC. This finding confirms the arguments made by of Morris and Roseman (2015) concerning the availability of cash and management temptation.

Based on this result, we reiterate the warnings against the increased liquidity in the hands of IBs' managers to avoid misconduct which may increase ACs.

The resulting outcome of the model for CBs before the crisis is presented in Table 10 below. 
Table 10. The results of the GLM panel data regression: Conventional before crisis

\begin{tabular}{rrcllrr}
\hline & Coef. & Robust Std. Err. & $\mathrm{Z}$ & $\mathrm{P}>|\mathrm{z}|$ & \multicolumn{2}{c}{ [95\% Conf. Interval] } \\
\hline$L o A, \boldsymbol{\beta}_{\boldsymbol{1}}$ & -.1228776 & .2122232 & -0.58 & 0.563 & -.5388275 & .2930722 \\
$D o A, \boldsymbol{\beta}_{2}$ & .0566383 & .1896507 & 0.30 & 0.765 & -.3150703 & .4283469 \\
$L o D, \boldsymbol{\beta}_{3}$ & .0799522 & .1717011 & 0.47 & 0.641 & -.2565757 & .4164802 \\
$C A o C L, \boldsymbol{\beta}_{4}$ & -.0003843 & .0005774 & -0.67 & 0.506 & -.0015159 & .0007474 \\
$R O A, \boldsymbol{\beta}_{5}$ & 4.916613 & .7344071 & 6.69 & $0.000^{* * *}$ & 3.477202 & 6.356024 \\
$R O E, \boldsymbol{\beta}_{\boldsymbol{6}}$ & -.6552469 & .0989934 & -6.62 & $0.000^{* * *}$ & -.8492704 & -.4612234 \\
$R I, \boldsymbol{\beta}_{7}$ & .0000547 & .0001067 & 0.51 & 0.608 & -.0001544 & .0002638 \\
$c$ cons, $\boldsymbol{\alpha}$ & .1042356 & .1490268 & 0.70 & 0.484 & -.1878517 & .3963228 \\
\hline
\end{tabular}

AC is the dependent variable, $\mathrm{R}^{2}=0.9039, \mathrm{~N}=84$

*** Significant at the $1 \%$ level

It appears that $\mathrm{AC}$ for $\mathrm{CBs}$ before the crisis is explained only by the profitability indicators. Similar to IBs, ROE has a negative effect on the $\mathrm{AC}$ for $\mathrm{CBs}$ before the crisis. This is, again, consistent with the proposition that better performance is associated with efficient management, hence, lower AC. The positive sign of ROA was interpreted earlier.

Table 11 depicts the outcome of estimating the model for CBs after the crisis.

Table 11. The results of the GLM panel data regression: Conventional after crisis

\begin{tabular}{rrcrrrr}
\hline & Coef. & Robust Std. Err. & \multicolumn{1}{l}{ Z } & \multicolumn{1}{r}{$\mathrm{P}>|\mathrm{z}|$} & \multicolumn{2}{r}{ [95\% Conf. Interval] } \\
\hline$L o A, \boldsymbol{\beta}_{\boldsymbol{1}}$ & -.0180329 & .0175346 & -1.03 & 0.304 & -.0524001 & .0163342 \\
$D o A, \boldsymbol{\beta}_{2}$ & -.0086432 & .0144907 & -0.60 & 0.551 & -.0370444 & .019758 \\
$L o D, \boldsymbol{\beta}_{3}$ & -.0016498 & .000977 & -1.69 & $0.091 *$ & -.0035647 & .0002651 \\
$C A o C L, \boldsymbol{\beta}_{4}$ & -.0001942 & .0002802 & -0.69 & 0.488 & -.0007434 & .0003551 \\
$R O A, \boldsymbol{\beta}_{5}$ & 6.978762 & .1973656 & 35.36 & $0.000^{* * *}$ & 6.591932 & 7.365591 \\
$R O E, \boldsymbol{\beta}_{\boldsymbol{6}}$ & -.9420406 & .052994 & -17.78 & $0.000 * * *$ & -1.045907 & -.8381742 \\
$R I, \boldsymbol{\beta}_{7}$ & -.0000294 & .0000639 & -0.46 & 0.646 & -.0001546 & .0000959 \\
$c o n s, \boldsymbol{\alpha}$ & .1586604 & .0289573 & 5.48 & $0.000^{* * *}$ & .1019051 & .2154156 \\
\hline
\end{tabular}

AC is the dependent variable, $\mathrm{R}^{2}=0.9569, \mathrm{~N}=84$

*** Significant at the $1 \%$ level, * Significant at the $10 \%$ level

\section{Discussion of the Results}

Considering only a significance level $<5 \%$, the results in Table 11 , indicate that the explanatory variables affecting AC of CBs after the crisis remained the same as before the crisis. The negative sign of the level of loans to deposits (at the $10 \%$ level) is also consistent with the proposition that better performance leads to lower AC.

The results of our mean rank analysis indicate that, while all the selected financial indicators changed after the crisis, the agency cost variable did not. Nevertheless, although the change was insignificant, CB were successful in lowering their agency cost, IBs were not. This result means that banks (both types) did not make serious efforts to lower their agency cost in response to the crisis.

The results of our causal models indicate that, for $\mathrm{CBs,} \mathrm{and} \mathrm{irrelevant} \mathrm{to} \mathrm{the} \mathrm{status} \mathrm{of} \mathrm{the} \mathrm{economy,} \mathrm{profitability}$ variables; namely ROE and ROA were the sole determinants of agency cost variability. Charts 2 and 3 show the significant drop of the two profit indicators after the crisis for conventional banks compared to their significant upsurge for Islamic banks. A possible explanation of this result is the fact that, at times of instability, regulators practice more control over lending which affects conventional banks more than Islamic banks. That is because, unlike CBs, IBs have a wider and more flexible venues to facilitate lending through the various Islamic instruments.

The increase of lending for IBs compared to that of CBs after the crisis is illustrated by chart 4 below. 


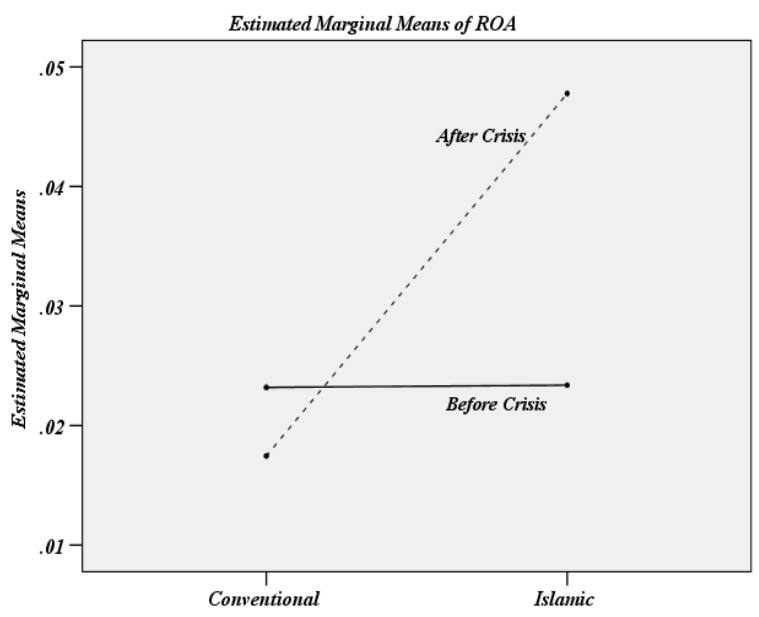

Chart 2. Estimated marginal means of ROA

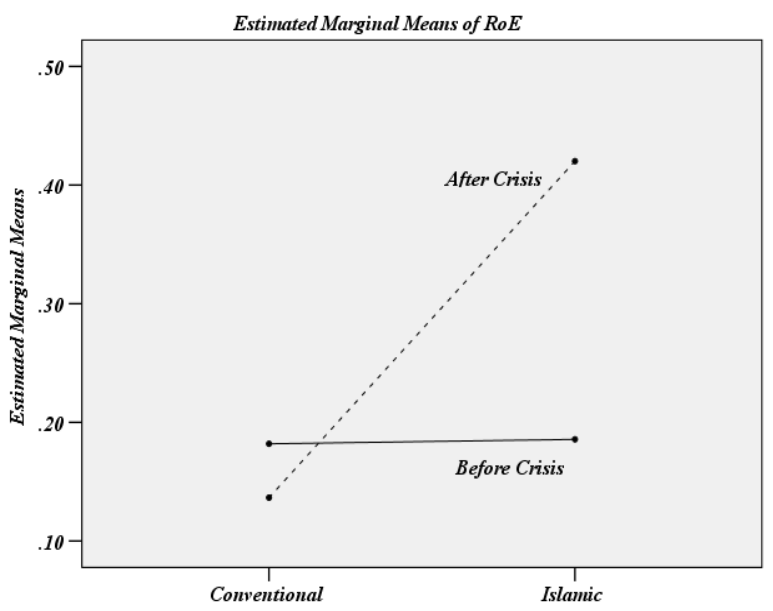

Chart 3. Estimated marginal means of ROA

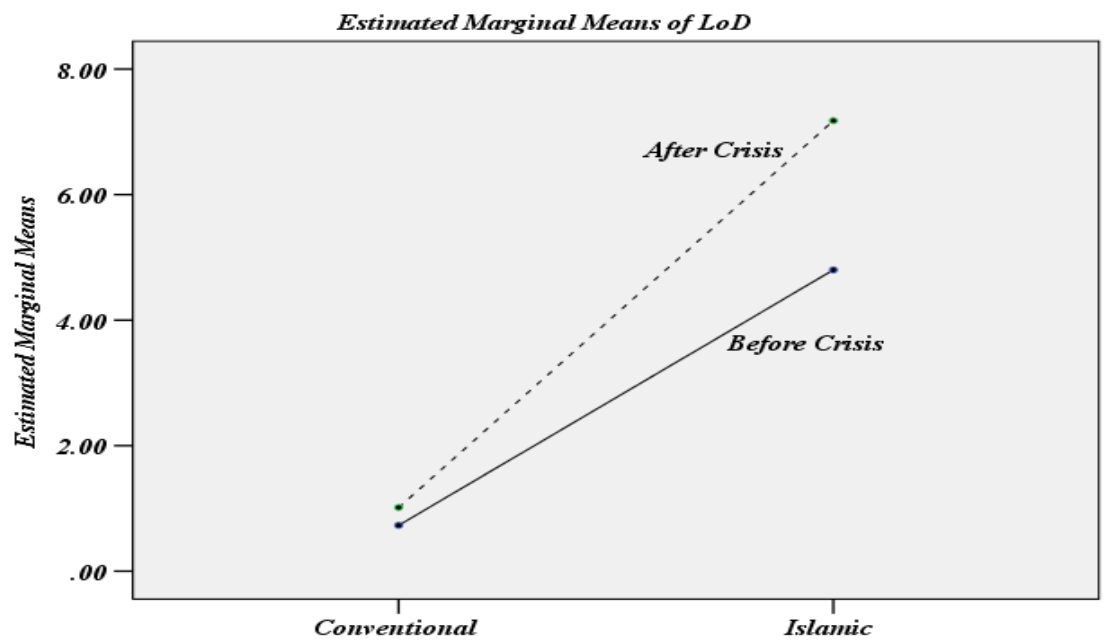

Chart 4. Estimated marginal means of lending to deposits 
Chart 4 lend support to the argument we made on charts 2 and 3. The effect of IBs lending flexibility is evident.

While the causal model of CB applies to IB after the crisis, it did not apply "before" the crisis. Although these results seem consistent with the propositions of agency theory, the causal models of CB and IB became the same after the crisis but not before the crisis. Since there was no significant change in our variable of concern, the change in the model after the crisis was caused by changes in the explanatory variables. For IB, our mean rank analysis indicates a significant increase of loans (Islamic facilities) to deposits and a significant decrease in deposits to assets.

For CBs in the GCC before and after the crisis, short-term liquidity, risk, and capital structure indicators are irrelevant to agency cost. The same applies for Islamic banks after the crisis except for liquidity. Before the crisis, however, the level of loans (Islamic facilities), short-term liquidity and risk index did not matter.

In conclusion, after the crisis, IBs and CBs have the same causal model indicating that they adopted similar measures. This is logical, as they were obliged to take measures in obedience to the same regulating bodies. Tables 12 and 13 below present a summary of the results.

Table 12. Summary results of hypotheses testing for mean ranks

\begin{tabular}{|c|c|c|c|c|c|}
\hline \multirow{41}{*}{ 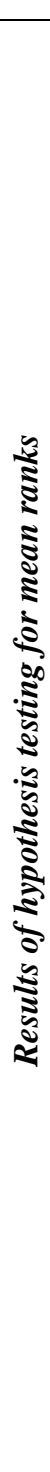 } & Hyp No. & Description & Variable & Supported & Un-Supported \\
\hline & \multirow{8}{*}{$\underset{1}{\text { Hyp }}$} & \multirow{8}{*}{$\begin{array}{l}\text { Irrespective of the } 2008 \\
\text { global financial crisis, } \\
\text { ACs variable and all of } \\
\text { the selected } \\
\text { performance variables } \\
\text { for IBs and CBs are } \\
\text { different. }\end{array}$} & $A C$ & & $\checkmark$ \\
\hline & & & LoA & $\checkmark$ & \\
\hline & & & $\overline{D o A}$ & $\checkmark$ & \\
\hline & & & LoD & $\checkmark$ & \\
\hline & & & $C A o C L$ & $\checkmark$ & \\
\hline & & & $R O A$ & $\checkmark$ & \\
\hline & & & $R O E$ & $\checkmark$ & \\
\hline & & & $R I$ & $\checkmark$ & \\
\hline & & & $A C$ & & \\
\hline & & ACs variable and all of & $L o A$ & $\checkmark$ & \\
\hline & & the selected & DoA & & $\checkmark$ \\
\hline & Нур & performance variables & $L o D$ & & $\checkmark$ \\
\hline & 2 & for IBs before the crisis & $C A o C L$ & $\checkmark$ & \\
\hline & & and after the crisis are & $R O A$ & $\checkmark$ & \\
\hline & & different. & $R O E$ & $\checkmark$ & \\
\hline & & & $R I$ & $\checkmark$ & \\
\hline & & & $A C$ & & $\checkmark$ \\
\hline & & ACs variable and all of & $L o A$ & & $\checkmark$ \\
\hline & & the selected & DoA & $\checkmark$ & \\
\hline & Hyp & performance variables & $L o D$ & & $\checkmark$ \\
\hline & 3 & for CBs before the & $C A o C L$ & $\checkmark$ & \\
\hline & & crisis and after the crisis & $R O A$ & $\checkmark$ & \\
\hline & & are different. & $R O E$ & $\checkmark$ & \\
\hline & & & $R I$ & & $\checkmark$ \\
\hline & & & $A C$ & & $\checkmark$ \\
\hline & & & LoA & $\checkmark$ & \\
\hline & & Before the crisis, ACs & DoA & $\checkmark$ & \\
\hline & Hyp & variable and all of the & $L o D$ & $\checkmark$ & \\
\hline & 4 & $\begin{array}{l}\text { selected performance } \\
\text { variables for IBs and }\end{array}$ & CAoCL & $\checkmark$ & \\
\hline & & CBs are different. & $R O A$ & & $\checkmark$ \\
\hline & & & $R O E$ & & $\checkmark$ \\
\hline & & & $R I$ & $\checkmark$ & \\
\hline & & & $A C$ & & $\checkmark$ \\
\hline & & & $L o A$ & $\checkmark$ & \\
\hline & & Atter the crisis, ACs & $\overline{D o A}$ & $\checkmark$ & \\
\hline & Hyp & variable and all of the & LoD & $\checkmark$ & \\
\hline & 5 & selected performance & $C A o C L$ & $\checkmark$ & \\
\hline & & $\begin{array}{l}\text { varrabies Ior IBs and } \\
\text { CBs are different }\end{array}$ & $R O A$ & $\checkmark$ & \\
\hline & & & $R O E$ & $\checkmark$ & \\
\hline & & & $R I$ & $\checkmark$ & \\
\hline
\end{tabular}


Table 13. Summary results of hypotheses testing for causal models

\begin{tabular}{|c|c|c|c|c|c|c|}
\hline & $\begin{array}{l}\text { Hyp } \\
\text { No. }\end{array}$ & Description & Variable & Supported & $\begin{array}{c}\text { Un-Suppor } \\
\text { ted }\end{array}$ & Sign \\
\hline \multirow{28}{*}{ 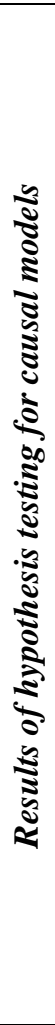 } & \multirow{7}{*}{$\begin{array}{c}\text { Hyp } \\
6-12\end{array}$} & \multirow{7}{*}{$\begin{array}{l}\text { Before the crisis, } \\
\text { each of the } \\
\text { selected } \\
\text { performance } \\
\text { indicators has a } \\
\text { significant effect } \\
\text { on AC of IBs. }\end{array}$} & LoA & & $\checkmark$ & \\
\hline & & & DoA & $\checkmark$ & & - \\
\hline & & & $L o D$ & $\checkmark$ & & - \\
\hline & & & $C A o C L$ & & $\checkmark$ & \\
\hline & & & $R O A$ & $\checkmark$ & & + \\
\hline & & & $R O E$ & $\checkmark$ & & - \\
\hline & & & $R I$ & & $\checkmark$ & \\
\hline & \multirow{7}{*}{$\begin{array}{c}\text { Hyp } \\
13-19\end{array}$} & \multirow{7}{*}{$\begin{array}{l}\text { After the crisis, } \\
\text { each of the } \\
\text { selected } \\
\text { performance } \\
\text { indicators has a } \\
\text { significant effect } \\
\text { on AC of IBs. }\end{array}$} & $L o A$ & & $\checkmark$ & \\
\hline & & & DoA & & $\checkmark$ & \\
\hline & & & $L o D$ & & $\checkmark$ & \\
\hline & & & $C A o C L$ & $\checkmark$ & & + \\
\hline & & & $R O A$ & $\checkmark$ & & + \\
\hline & & & $R O E$ & $\checkmark$ & & - \\
\hline & & & $R I$ & & $\checkmark$ & \\
\hline & \multirow{7}{*}{$\underset{20-26}{\text { Hyp }}$} & \multirow{7}{*}{$\begin{array}{l}\text { Before the crisis, } \\
\text { each of the } \\
\text { selected } \\
\text { performance } \\
\text { indicators has a } \\
\text { significant effect } \\
\text { on AC of CBs. }\end{array}$} & $L o A$ & & $\checkmark$ & \\
\hline & & & DoA & & $\checkmark$ & \\
\hline & & & $L o D$ & & $\checkmark$ & \\
\hline & & & $C A o C L$ & & $\checkmark$ & \\
\hline & & & $R O A$ & $\checkmark$ & & + \\
\hline & & & $R O E$ & $\checkmark$ & & - \\
\hline & & & $R I$ & & $\checkmark$ & \\
\hline & \multirow{7}{*}{$\begin{array}{c}\text { Hyp } \\
27-33\end{array}$} & \multirow{7}{*}{$\begin{array}{l}\text { After the crisis, } \\
\text { each of the } \\
\text { selected } \\
\text { performance } \\
\text { indicators has a } \\
\text { significant effect } \\
\text { on AC of CBs. }\end{array}$} & $L o A$ & & $\checkmark$ & \\
\hline & & & $D o A$ & & $\checkmark$ & \\
\hline & & & $L o D$ & & $\checkmark$ & \\
\hline & & & $C A o C L$ & & $\checkmark$ & \\
\hline & & & $R O A$ & $\checkmark$ & & + \\
\hline & & & $R O E$ & $\checkmark$ & & - \\
\hline & & & $R I$ & & $\checkmark$ & \\
\hline
\end{tabular}

\section{Conclusion}

In this paper, we examined the agency cost of CBs and IBs before and after the 2008 global financial crisis in the GCC region. We covered all banks that satisfied the desired period. Agency cost is our variable of interest. Seven performance indicators were elected to measure their effects on the variability of bank agency cost before and after the crisis.

Differences in variables before and after the crisis were tested using nonparametric mean rank tests. GLS panel data regressions were estimated to investigate causal modeling.

We provide no evidence of significant change in the agency cost in response to the global financial crisis for both types of banks. Our results, however, show that the agency cost causal models for Islamic banks and conventional banks, before and after the crisis are different. For CBs, We provided evidence of no change in causal model before and after the crisis involving only the two profitability variables. For IBs, before and after the crisis, the profitability variables remained significant determinants of agency cost. However, deposits and finance facilities were also found to be significant determinants of agency cost before the crisis and liquidity was found to be a significant determinant after the crisis.

Our results show that neither CBs nor IBs in the GCC region have made substantial efforts to reduce their agency costs in response to the 2008 global financial crisis. Profitability of both bank types is found to be a significant determinant of agency cost variability. As such, the mean rank of CBs' ROE was significantly higher that of IBs. Moreover, at times of stability (i.e., before the crisis) deposits and financing facilities have explanatory power towards agency costs of IBs and at times financial distress liquidity affects. These results imply that, on the one hand, both CBs and IBs should take profitability (ROE) seriously when trying to reduce their ACs. On the other hand, and in addition to profitability factors, IBs should look closely at their the levels of investment accounts and financing facilities at times of stability and the level of liquidity at times of volatility when trying to reduce their agency costs.

Although we have covered an important region containing the highest mix of Islamic and conventional banks, further research to cover other regions in the world and other performance variables are highly recommended. Furthermore, it would be even more interesting to investigate other representations of agency costs. 


\section{References}

Aldeehani, T., Karim, R. A., \& Murinde, V. (1999), The Capital Structure of Islamic Banks Under the Contractual Obligation of Profit Sharing, International Journal of Theoretical and Applied Finance, 2(3), 43-283. https://doi.org/10.1142/S0219024999000157

Aljifri, K., \& Kumar, K. S. (2013). Financial Contracts in Conventional and Islamic Financial Institutions: An Agency Theory Perspective, Review of Business and Finance Studies, 4(2), 79-88.

AlQanea, M. K., \& Hamdan, A. M. M. (2017). Islamic banks board independence and its relation to performance in GCC countries. International Journal of Islamic Marketing and Branding, 2(2), 100-121. https://doi.org/10.1504/IJIMB.2017.084810

Ang, J. S., Cole, R. A., \& Lin, J. W. (2000). Agency costs and ownership structure. The Journal of Finance, 55(1), 81-106. https://doi.org/10.1111/0022-1082.00201

Archer, S., Karim, R. A., \& Aldeehani, T. (1998). Financial Contracting, Governance Structure and the Accounting Regulation of Islamic Banks: An Analysis in Terms of Agency Theory and Transaction Cost Economics, Journal of Management and Governance, 2, 149-170. https://doi.org/10.1023/A:1009985419353

Arouri, H., Hossain, M., \& Muttakin, M. B. (2011). Ownership structure, corporate governance and bank performance: evidence from GCC countries. Corporate Ownership and Control, 8(4D), 365-372. https://doi.org/10.22495/cocv8i4c3art5

Berger, A. N., \& Di Patti, E. B. (2006). Capital structure and firm performance: A new approach to testing agency theory and an application to the banking industry. Journal of Banking \& Finance, 30(4), 1065-1102. https://doi.org/10.1016/j.jbankfin.2005.05.015

Doukas, J. A., Kim, C., \& Pantzalis, C. (2000). Security analysis, agency costs, and company characteristics. Financial Analysts Journal, 56(6), 54-63. https://doi.org/10.2469/faj.v56.n6.2403

Easterbrook, F. H. (1984). Two agency-cost explanations of dividends. The American Economic Review, 74(4), 650-659.

Fayed, M., \& Ezzat, A. (2017). Do principal-agent conflicts impact performance and risk-taking behavior of Islamic banks? Topics in Middle Eastern and African Economies, Proceedings of Middle East Economic Association, 19(2), $32-66$.

Florackis, C. (2008). Agency costs and corporate governance mechanisms: Evidence for UK firms. International Journal of Managerial Finance, 4(1), 37-59. https://doi.org/10.1108/17439130810837375

Gul, S., Sajid, M., Razzaq, N., \& Afzal, F. (2012). Agency cost, corporate governance and ownership structure (the case of Pakistan). International Journal of Business and Social Science, 3(9), 268-277.

Harun, M. S. B. (2016). The impact of corporate governance and its consequences on CSR disclosure: empirical evidence from Islamic banks in GCC countries, a doctoral thesis of the University of Plymouth, https://pearl.plymouth.ac.uk/handle/10026.1/6608

Imran, K., Usman, M., \& Nishat, M. (2013). Banks dividend policy: Evidence from Pakistan. Economic Modelling, 32, 88-90. https://doi.org/10.1016/j.econmod.2013.01.041

Ismail, A. G., \& Pratomo, W. A. (2007). Islamic Bank Performance and Capital Structure1. In Paper presented at Workshop in Islamic Financial Markets and Institutions (Vol. 27, p. 28February).

Meero, A. A. (2015). The Relationship between Capital Structure and Performance in Gulf Countries Banks: A Comparative Study between Islamic Banks and Conventional Banks. International Journal of Economics and Finance, 7(12), 140-154. https://doi.org/10.5539/ijef.v7n12p140

Mohammed, D. (2013). A dynamic panel model of capital structure and agency cost in Nigerian listed companies, Global Conference on Business and Finance Proceedings, 8(1), 145-153. https://papers.ssrn.com/sol3/papers.cfm?abstract_id=2323656

Morris, B. C., \& Roseman, B. S. (2014). Dividends as a solution to agency cost and opaqueness: Theory and evidence. International Journal of Economics and Finance, 7(1), 24. https://doi.org/10.5539/ijef.v7n1p24

Naushad, M., \& Malik, S. A. (2015). Corporate Governance and Bank Performance: A Study of Selected Banks in GCC Region. Asian Social Science, 11(9), 226-234. https://doi.org/10.5539/ass.v11n9p226

Rahman, R. A., Saimi, N. S., \& Danbatta, B. L. (2016). Determinants of Ethical Identity Disclosure in Islamic Banks: An Analysis of Practices in Bahrain and Malaysia. Jurnal Pengurusan (UKM Journal of Management), 46, 13-22.

Rashid, A. (2015). Revisiting agency theory: Evidence of board independence and agency cost from Bangladesh. 
Journal of Business Ethics, 130(1), 181-198. https://doi.org/10.1007/s10551-014-2211-y

Safieddine, A. (2009). Islamic financial institutions and corporate governance: New insights for agency theory. Corporate Governance: An International $\quad$ Review, $\quad 17(2), \quad$ 142-158. https://doi.org/10.1111/j.1467-8683.2009.00729.x

Shoaib, A. (2011). Measuring performance through capital structure: Evidence from banking sector of Pakistan. African Journal of Business Management, 5(5), 1871-1879.

Singh, M., \& Davidson III, W. N. (2003). Agency costs, ownership structure and corporate governance mechanisms. Journal of Banking \& Finance, 27(5), 793-816. https://doi.org/10.1016/S0378-4266(01)00260-6

Wellalage, N. H., \& Locke, S. (2012). An empirical investigation of agency costs and ownership structure in unlisted small businesses, New Zealand Journal of Applied Business Research, 10(2) 37-48.

Yeh, T. L. (2011). Capital structure and cost efficiency in the Taiwanese banking industry. The Service Industries Journal, 31(2), 237-249. https://doi.org/10.1080/02642060802710230

Zeitun, R. (2012). Determinants of Islamic and conventional banks performance in GCC countries using panel data analysis. Global Economy and Finance Journal, 5(1), 53-72.

Zheng, M. (2013). Empirical research of the impact of capital structure on agency cost of Chinese listed companies. International Journal of Economics and Finance, 5(10), 118-125. https://doi.org/10.5539/ijef.v5n10p118

\section{Copyrights}

Copyright for this article is retained by the author(s), with first publication rights granted to the journal.

This is an open-access article distributed under the terms and conditions of the Creative Commons Attribution license which permits unrestricted use, distribution, and reproduction in any medium, provided the original work is properly cited. 